\title{
Effects of Early Visual Experience and Diurnal Rhythms on BDNF mRNA and Protein Levels in the Visual System, Hippocampus, and Cerebellum
}

\author{
Graeme S. Pollock, ${ }^{1}$ Elizabeth Vernon, ${ }^{3}$ M. Elizabeth Forbes, ${ }^{3}$ Qiao Yan, ${ }^{4}$ Yun-Tao Ma, ${ }^{1}$ Ted Hsieh, ${ }^{1}$ \\ Regine Robichon, ${ }^{1}$ Douglas O. Frost, ${ }^{1,2}$ and James E. Johnson ${ }^{3}$ \\ ${ }^{1}$ Department of Pharmacology and Experimental Therapeutics and 2Department of Anesthesiology and Neuroscience \\ Program, University of Maryland School of Medicine, Baltimore, Maryland 21201, ${ }^{3}$ Department of Neurobiology and \\ Anatomy, Wake Forest University School of Medicine, Winston-Salem, North Carolina 27157, and ${ }^{4}$ Department of \\ Neuroscience, Amgen, Inc., Thousand Oaks, California 91320
}

The expression of brain-derived neurotrophic factor (BDNF) mRNA and the secretion of BDNF protein are tightly regulated by neuronal activity. Thus, BDNF has been proposed as a mediator of activity-dependent neural plasticity. Previous studies showed that dark rearing (DR) reduces BDNF mRNA levels in the primary visual cortex (V1), but the effects of visual experience on BDNF protein levels are unknown. We report that rearing in constant light or DR alters BDNF $\mathrm{mRNA}$ and protein levels in the retina, superior colliculus (SC), V1, hippocampus (HIPP), and cerebellum (CBL), although the changes in mRNA and protein are not always correlated. Most notably, DR increases BDNF protein levels in V1 although BDNF mRNA is decreased. BDNF protein levels also undergo diurnal changes. In the retina, V1, and SC, BDNF protein levels are higher during the light phase of the circadian cycle than during the dark phase. By contrast, in HIPP and CBL, the tissue concentration of BDNF protein is higher during the dark phase. The discrepancies between the experience-dependent changes in BDNF mRNA and protein suggest that via its effects on neuronal activity, early sensory experience alters the trafficking, as well as the synthesis, of BDNF protein. The circadian changes in BDNF protein suggest that BDNF could cause the diurnal modulation of synaptic efficacy in some neural circuits. The fluctuations in BDNF levels in nonvisual structures suggest a potential role of BDNF in mediating plasticity induced by hormones or motor activity.

Key words: neurotrophin; development; deprivation; brainderived neurotrophic factor; visual cortex; superior colliculus; plasticity; dark rearing; light rearing; rat; hamster
During ontogeny, the distribution and strength of neural connections are modified by the level and pattern of neuroelectric activity (Cowan et al., 1984; Katz and Shatz, 1996). Consequently, sensory experience exerts a powerful influence on the sculpting of developing neural circuits. This process is widely studied in the mammalian visual system (Sherman and Spear, 1982; Fregnac and Imbert, 1984; Frost and Innocenti, 1986). Visual experience regulates the growth, stabilization, and elimination of immature thalamocortical connections representing each eye and the response properties of cortical neurons (Hubel et al., 1977; Sherman and Spear, 1982; Fregnac and Imbert, 1984).

Developing cortical synapses can be strengthened or weakened, depending on the level of presynaptic axonal activity and postsynaptic neuronal depolarization (Bienenstock et al., 1982; Miller et al., 1989). Neurotrophins, including brain-derived neurotrophic

Received Dec. 8, 2000; revised March 5, 2001; accepted March 16, 2001.

This work was supported by National Institutes of Health (NIH) Grants EY11127 (J.E.J. and M.E.F.), MH49568, and EY11434 (D.O.F., G.S.P., T.H., and R.R.), by NIH Training Grant NS07375 (Y.-T.M.), by a Special Research Initiative Support grant from the University of Maryland (D.O.F.), and by the Wake Forest University School of Medicine (J.E.J.). We thank Deb Medoff for statistical analysis and Paul Fishman, Bai Lu, Frank Margolis, Ron Oppenheim, David Riddle, Barry Stein, and Mark Wallace for critical comments and discussions.

G.S.P., D.O.F., and J.E.J. contributed equally to this report.

Correspondence should be addressed to Dr. Douglas O. Frost, Department of Pharmacology and Experimental Therapeutics, University of Maryland School of Medicine, 655 West Baltimore Street, Baltimore, MD 21201. E-mail: dfrost@ umaryland.edu.

Copyright () 2001 Society for Neuroscience $0270-6474 / 01 / 213923-09 \$ 15.00 / 0$ factor (BDNF), have been proposed as retrograde signaling molecules that contribute to the bidirectional synaptic communication that modulates the efficacy and stability of connections (Domenici et al., 1991; Snider and Lichtman, 1996; Shatz, 1997). These molecules control many other developmental events, including neuronal survival and differentiation (Lewin and Barde, 1996). Neurotrophins also selectively modify the growth of developing axons (Cabelli et al., 1995; Cohen-Cory and Fraser, 1995; Inoue and Sanes, 1997; Cohen-Cory, 1999) and dendrites (McAllister et al., 1995; Schwartz et al., 1997; Horch et al., 1999; Lom and Cohen-Cory, 1999; Xu et al., 2000) and the density of synapses (Causing et al., 1997). BDNF and its high-affinity receptor trkB are highly expressed in the mature hippocampus and cerebral cortex, regions of the mature brain notable for experience-dependent synaptic plasticity (Thoenen, 1995). BDNF mRNA expression within these regions is rapidly induced by various forms of neural activity [membrane depolarization (Zafra et al., 1992; Ghosh et al., 1994), activation of excitatory neurotransmitter receptors (Zafra et al., 1990, 1992; Lindefors et al., 1992; Bessho et al., 1993; Ghosh et al., 1994; Knipper et al., 1994; Lindholm et al., 1994), seizures (Gall, 1993; Gall et al., 1995), and stimuli that induce long-term potentiation (Patterson et al., 1992)]. Antagonization of neuronal depolarization or augmented hyperpolarization (Zafra et al., 1991; Lindefors et al., 1992; Knipper et al., 1994; Lindholm et al., 1994) decreases BDNF mRNA expression. Alterations of visual experience, via their effects on neural activity, regulate BDNF mRNA synthesis. 
BDNF mRNA expression is reduced in the primary visual cortex (V1) of rodents and carnivores after dark rearing (DR) (Castrén et al., 1992; Schoups et al., 1995; Lein et al., 1997) or retinal impulse blockade by intraocular injection of tetrodotoxin (Castrén et al., 1992; Bozzi et al., 1995; Lein et al., 2000). In rodents, deprivation of pattern vision by eyelid suture reduces BDNF mRNA by $~ 55 \%$ (Bozzi et al., 1995); DR reduces BDNF mRNA by 25-40\% (Castrén et al., 1992; Schoups et al., 1995). The rapid increase of cortical BDNF mRNA induced in V1 of DR animals that are later exposed to light (Castrén et al., 1992; Schoups et al., 1995) shows that BDNF synthesis in V1 is tightly regulated by sensory experience.

Because BDNF is a secretory protein (Mowla et al., 1999) that can be distributed by axonal transport in the retrograde (von Bartheld et al., 1996; Ma et al., 1998) or anterograde (Zhou and Rush, 1996; Altar et al., 1997; Conner et al., 1997; Fawcett et al., 1997, 1998; Smith et al., 1997; Haubensak et al., 1998) directions, we reasoned that the effects of early visual experience on local levels of BDNF mRNA and BDNF protein might not be the same. This is important for understanding the role of BDNF in mediating effects of sensory experience on neural structure and function, because protein, not mRNA, is the effector molecule. Measurements of activity-dependent changes in BDNF protein and comparisons of the effects of neural activity on BDNF mRNA and protein have been made in only a few instances (Nawa et al., 1995; Elmer et al., 1998). Therefore, we compared the effects of rearing in constant light and constant darkness on the levels of BDNF mRNA and BDNF protein in several visual and nonvisual neural structures.

Previous studies have demonstrated diurnal modulation of BDNF mRNA (Bova et al., 1998; Berchtold et al., 1999; Schaaf et al., 2000) and trkB mRNA (Bova et al., 1998) levels. Thus, we investigated whether these changes are sufficient to produce circadian variations in the tissue concentrations of BDNF protein.

\section{MATERIALS AND METHODS}

Subjects and experimental rearing. Our initial BDNF protein measurements were made in Syrian golden hamsters (Mesocricetus auratus) because the CNS of this mammal is one of the least mature at birth and it has proven a valuable model of visual system development. All of our combined mRNA and protein measurements were made in pigmented rats (Long-Evans) because we were unable to generate a reliable probe for the measurement of hamster BDNF mRNA. Rats and hamsters were born and reared either in a normal light cycle (14/10 hr light/dark cycle), constant light (LR), or constant darkness (DR). The cages of the DR animals were serviced in total darkness. DR animals were killed in total darkness, so they were never exposed to light. All protocols were approved by our institutional animal care and use committees and follow National Institutes of Health guidelines.

Preparation of samples for BDNF protein measurement. All rats were killed with an overdose of Nembutal and decapitated on postnatal day 21 (P21) (day of birth, P0) for consistency with previous studies (Castrén et al., 1992; Schoups et al., 1995). Hamsters were killed on P29 when BDNF protein levels in the retina and superior colliculus (SC) have reached mature values (Ma et al., 1997, 1998) (D. O. Frost, Y.-T. Ma, T. Hsieh, M. E. Forbes, and J. E. Johnson, unpublished observations). All normally reared animals were killed during the morning, in the middle of the light phase of the circadian cycle. All LR and DR animals were killed at the same time of day so that the only difference in environmental conditions at the time of their death was their history of light exposure. Additional adult (P90 or older) hamsters reared on a normal light cycle were killed in the middle of the light or dark phase of the diurnal cycle. The brains of all animals were rapidly removed from the skull. The V1, SC, hippocampus (HIPP), cerebellum (CBL), and retinas were rapidly dissected in cold PBS $\left(4^{\circ} \mathrm{C}\right), \mathrm{pH} 7.4$, and snap frozen in isopentane cooled by dry ice. Tissue samples were stored at $-85^{\circ} \mathrm{C}$ before homogenization. BDNF was extracted from brain tissue by homogenization in $100 \mathrm{~mm}$ PIPES homogenization buffer, $\mathrm{pH} 7.0$, containing $500 \mathrm{~mm} \mathrm{NaCl}, 2 \%$ BSA, $0.2 \%$ Triton $\mathrm{X}-100,0.1 \% \mathrm{NaN}_{3}$, and fresh protease inhibitors $(2 \mu \mathrm{g} / \mathrm{ml}$ aprotinin, 2 mM EDTA, $10 \mu \mathrm{M}$ leupeptin, $1 \mu \mathrm{M}$ pepstatin, and $200 \mu \mathrm{M}$ PMSF) and homogenized using ground-glass Dounces. Homogenates were centrifuged at $16,000 \times g$ for $20 \mathrm{~min}$ to pellet insoluble material. Supernatants were collected and stored at $-85^{\circ} \mathrm{C}$ before BDNF electrochemiluminescent immunoassay (ECLIA).

The dilution of the tissue in homogenization buffer (milligrams per microliter) varied with species and tissue. Tissue dilution affects the efficiency of BDNF recovery (Ma et al., 1998) (J. E. Johnson, M. E. Forbes, and Q. Yan, unpublished observations). Thus, our measurements of BDNF protein accurately reflect differences among rearing conditions (or diurnal phases) in a single tissue, but comparisons among brain regions or between species are not warranted. In our original experiments comparing normally reared, DR, and LR hamsters with respect to BDNF protein levels in V1 and SC, the dilutions used were 1:75. Other experiments showed a linear increase in extracted BDNF over a range of tissue dilutions (1:25-1:200) (Ma et al., 1998). Our extraction method results in $\sim 80 \%$ recovery of an exogenous recombinant human BDNF spike at 1:200 (Ma et al., 1998). Higher dilutions were not tested because of the resulting decrease in signal. Thus, in the studies of normal, LR, and DR hamsters, our BDNF protein measurements in V1 and SC were adjusted to reflect the values expected for a 1:200 dilution of SC $(2.205 \times)$ and should be regarded as minimum estimates of BDNF tissue concentrations. In our studies of circadian modulation of BDNF protein levels, tissues fromV1, SC, and CBL were diluted at 1:75, the hippocampus was diluted at 1:100, and the retina was diluted at 1:200. Dilutions for rat tissue were as follows: 1:150 (V1), 1:200 (SC), 1:75 (CBL and retina), and 1:100 (HIPP). Accurate measurements of relative BDNF protein are highly reproducible in tissues homogenized at identical dilutions. Additional details of sample preparation and control experiments are described elsewhere (Ma et al., 1998) (Johnson, Forbes, and Yan, unpublished observations).

ECLIA measurement of BDNF protein. Immunoassays used an affinitypurified BDNF-specific rabbit polyclonal antibody (Rab-BDNF) (Yan et al., 1997) in an immunomagnetic sandwich assay with a detection limit of $\sim 0.835 \mathrm{pg}$ of BDNF per milligram of tissue and a dynamic range of $\sim 10^{3}$ (Johnson, Forbes, and Yan, unpublished observations). BDNF is captured from tissue homogenate supernatants via Rab-BDNF-biotinylated antibodies bound to streptavidin-coated Dynal $2.8 \mu \mathrm{m}$ magnetic beads. In the same one-step reaction, signal TAG-labeled (Igen, Inc., Rockville, MD) Rab-BDNF antibodies bind to the BDNF homodimer. BDNF protein is then measured by the electrochemiluminescence (ECL) signal emitted from current stimulation of Rab-BDNF-TAG bound to beads captured by a magnet in an Origen analyzer (Igen, Inc.). One hundred fifty microliters of ECLIA reaction mixture $(12.5 \mathrm{ng}$ of biotinylated Rab-BDNF, $25 \mathrm{ng}$ of Rab-BDNF-TAG, and $10 \mu \mathrm{g}$ of Dynal $2.8 \mu \mathrm{m}$ M-280 streptavidin magnetic beads diluted in $\mathrm{Ca}^{2+}$ - and $\mathrm{Mg}^{2+}$-free Dulbecco's PBS, pH 7.2, containing 3\% BSA, 1.5\% Tween 20, and $0.05 \%$ $\mathrm{NaN}_{3}$ ) were added to $100 \mu \mathrm{l}$ of tissue supernatant unknowns aliquoted in $12 \times 75 \mathrm{~mm}$ polypropylene tubes. Sample reaction mixtures were vortexed for $90 \mathrm{~min}$ using the Origen Analyzer carousel. The reaction was terminated by the addition of $250 \mu \mathrm{l}$ of Origen Assay Buffer (Igen, Inc.) per tube. ECL counts were measured sequentially from each sample using the Origen Analyzer. Counts from homogenization buffer (blanks) were subtracted from all values. BDNF concentrations for tissue supernatants were calculated from regression analysis of a human recombinant BDNF standard curve (diluted in homogenization buffer) run in each assay.

Total RNA isolation. Fifteen to 20 animals per condition were killed. For each tissue region, we pooled blocks from three to five animals (depending on the weight of the region) to obtain the $200-300 \mathrm{mg}$ of tissue required to produce 200-300 $\mu \mathrm{g}$ of RNA for each sample. Four to five RNA samples for each region were prepared using Trizol reagent (Life Technologies, Gaithersburg, MD) according to the manufacturer's procedures.

Ribonuclease protection assay. BDNF mRNA levels were measured using a Riboquant Multiprobe RNase protection assay (RPA) system and a rat neurotrophin multiprobe template set (which also measures RNA constitutively expressed by the glyceraldehyde-3-phosphate dehydrogenase and L32 genes) according to the manufacturer's (PharMingen, San Diego, CA) instructions. RNase-protected fragments were sizefractionated using the Quickpoint precast $6 \%$ polyacrylamide and $7 \mathrm{M}$ urea gel system (Novex, San Diego, CA). Gels were exposed to PhosphorImager plates (Molecular Dynamics, Sunnyvale, CA) and scanned 
using a Molecular Dynamics Storm 840 system. Average pixel densities of protected band fragments were measured and analyzed using Molecular Dynamics Imagequant, version 5.0 for Windows. Background pixel densities were subtracted from protected fragment band intensities and normalized according to the densities of L32 fragments (see Statistical analysis).

Statistical analysis. In our measurements of BDNF protein, for each tissue region, samples from LR, DR, and normal animals were processed in parallel in the same ECLIA run. Thus, for each region, we determined the statistical significance of differences in BDNF protein levels between LR or DR animals and normal animals (or light-phase and dark-phase animals) using a Mann-Whitney $U$ test, two-tailed. Because of intergel variability and the intrinsic variability in the quantity of RPA products loaded in each lane on a gel, the PhosphorImager data were analyzed by two-way ANOVA, covarying for the L32 signal and adjusting for differences among gels. All quantitative mRNA values reported are corrected according to the variability of the L32 signals in each gel.

\section{RESULTS}

\section{In the visual cortex, dark rearing decreases BDNF mRNA but increases BDNF protein levels}

In agreement with previous studies (Castrén et al., 1992; Schoups et al., 1995), DR induced a downregulation of BDNF mRNA in rats to $\sim 65 \%$ of normal values ( $p=0.003$; Figs. $1 B, 2$; Table 1$)$. Surprisingly, in both hamsters and rats we observed the highest concentration of BDNF protein in $\mathrm{V} 1$ when the animals were born and reared in complete darkness (Fig. $1 A$ ). In V1 of DR hamsters, the concentration of BDNF protein (mean $\pm \mathrm{SD}$ ) was $56 \pm 12 \mathrm{pg} / \mathrm{mg}, 2.2 \times$ the concentration in $\mathrm{V} 1$ of normally reared hamsters $(p=0.0062$; Fig. $1 A)$ and $1.3 \times$ the concentration in hamsters reared in constant light ( $p=0.0472$; Fig. $1 A)$. In rats, DR induced an $\sim 35 \%$ increase $(p=0.025)$ in BDNF protein $(8.7 \pm 1.5 \mathrm{pg} / \mathrm{mg})$ as compared with normal $(6.4 \pm 0.3 \mathrm{pg} / \mathrm{mg})$. The magnitude and direction of the change in BDNF protein concentration were unexpected based on the DR-induced depression in BDNF mRNA expression observed by us and by others (Castrén et al., 1992; Schoups et al., 1995). These results indicate that a substantial accumulation of BDNF protein occurs in V1 of DR animals despite the reduction of BDNF mRNA in the same region.

\section{Light rearing increases visual cortical BDNF levels}

In hamster V1, constant light rearing elevated BDNF protein levels to $\sim 38 \pm 12 \mathrm{pg} / \mathrm{mg}$ as compared with $25 \pm 3 \mathrm{pg} / \mathrm{mg}$ in animals reared on a normal light cycle $(p=0.0285$; Fig. $1 A)$. This increase, of $\sim 50 \%$, was expected because of the tight regulation of visual cortical BDNF mRNA by sensory experience (Castrén et al., 1992; Schoups et al., 1995). However, in rat V1, LR induced only weak increases in BDNF mRNA and BDNF protein that were not statistically significant ( $p>0.05$; Figs. $1 A, B, 2$; Table 1$)$. Whereas we cannot exclude a species difference, the more robust increases in BDNF protein in hamsters than in rats might be caused by the longer periods of LR and DR in our hamster experiments.

\section{In the SC, light rearing and dark rearing induce changes in BDNF mRNA and protein levels that are not correlated}

To determine whether LR or DR modify the concentrations of BDNF mRNA or protein in other visual system structures, we also measured the concentration of BDNF mRNA and protein in SC. In both hamsters and rats, there were no significant intergroup differences in the collicular concentration of BDNF protein $(p>0.05$; Fig. $1 A)$. LR increases BDNF mRNA levels in the rat by $27 \%(p=0.002$; Fig. $1 B$; Table 1$)$, whereas DR has no significant effect on BDNF mRNA expression.

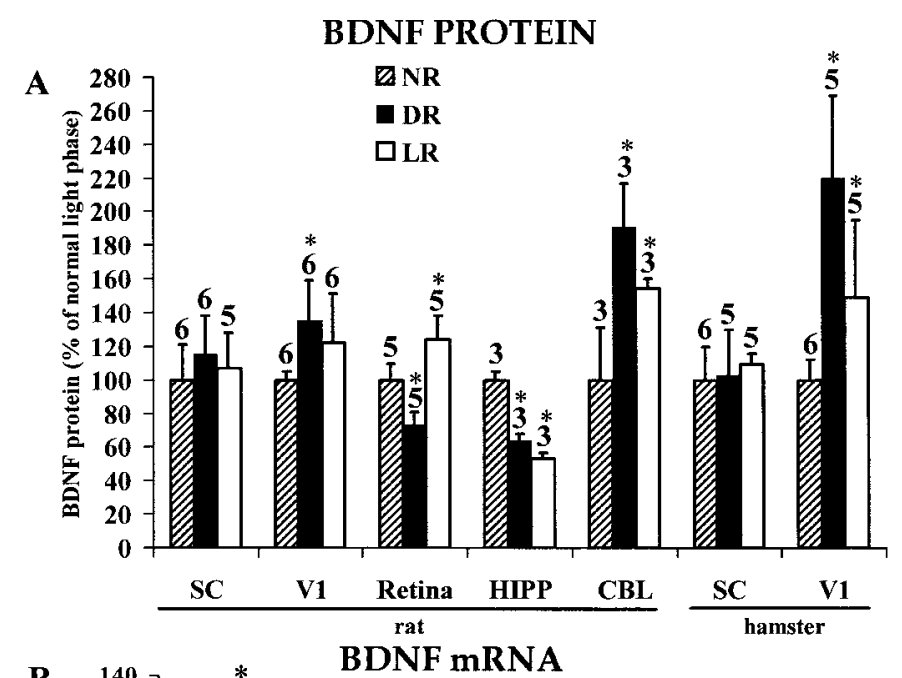

$\mathbf{B}$
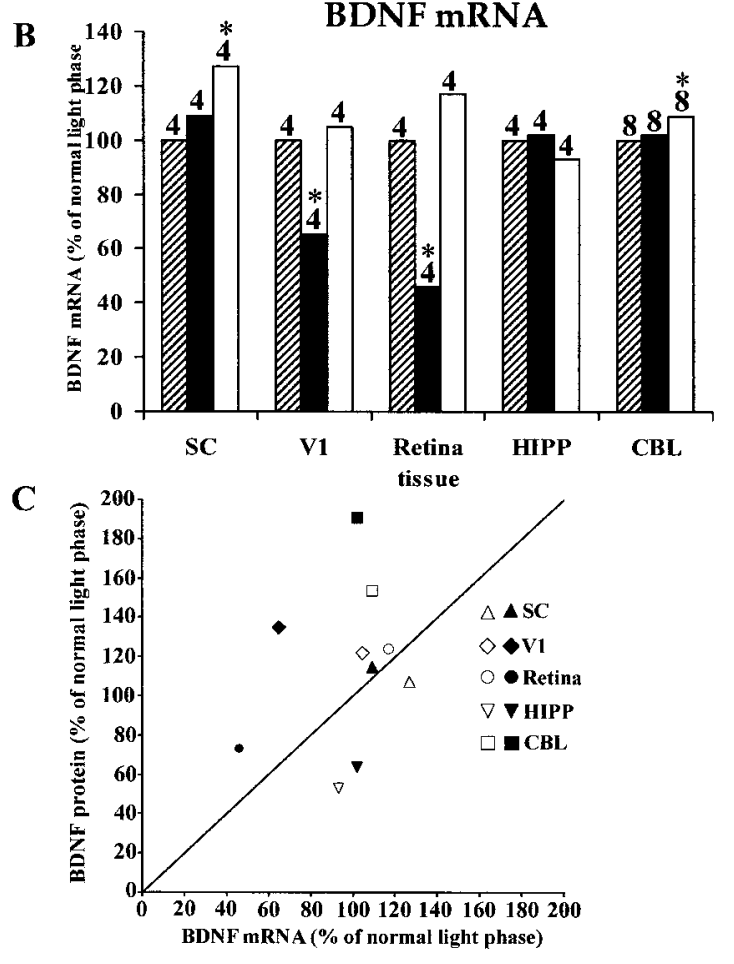

Figure 1. A, ECLIA measurements of BDNF protein concentrations in the SC, V1, retina, HIPP, and CBL of rats born and reared in a normal light cycle $(N R ; 14 / 10 \mathrm{hr}$ light/dark cycle), constant darkness (DR), or constant light (LR). Similar measurements for SC and V1 are presented for hamsters at the right. All values are expressed as the percentage of normal. Error bars show SD. Numbers above each bar indicate the number of independent samples from which data were obtained (see Materials and Methods). $B$, RPA measurements of BDNF mRNA concentrations in rats in the same structures and under the same rearing conditions shown in $A$. All values are expressed as the percentage of normal. Numbers above each bar indicate the number of independent samples from which data were obtained (see Materials and Methods). Means and SEs of PhosphorImager pixel densities are indicated in Table 1. $C$, Scatter plot summarizing the relationship between changes in BDNF mRNA and BDNF protein induced in rats by DR (filled symbols) and LR (open symbols). Asterisks in $A$ and $B$ indicate values in LR or DR animals that differ significantly from normal.

In hamsters, LR and DR both increase BDNF protein levels in $\mathrm{V} 1$ but produce no change in SC. This similarity of effect raises the possibility that LR might induce photoreceptor degeneration, as in albino rats (O’Steen et al., 1974). Three observations argue 


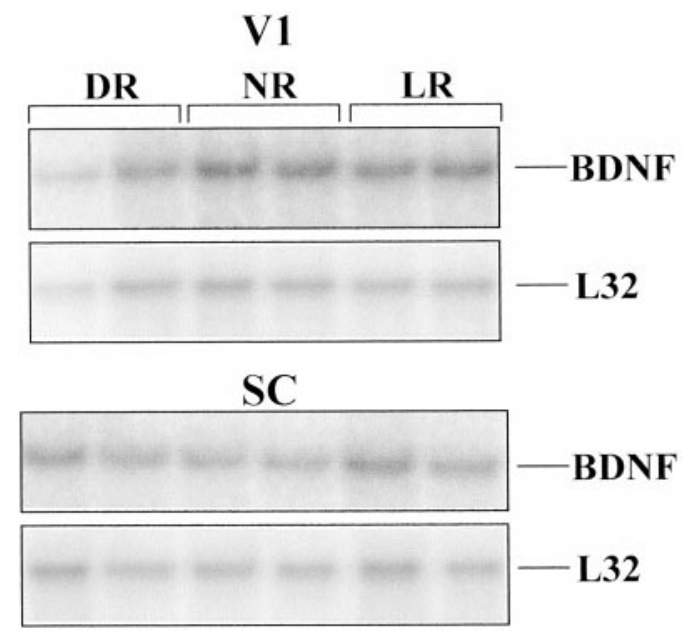

Figure 2. Protected mRNA fragments corresponding to BDNF and the L32 housekeeping protein, obtained by performing the ribonuclease protection assay on mRNA from rat V1 (top) and rat SC (bottom). Two cases are shown for each tissue for each of the three rearing conditions (NR, DR, and LR). Gels were aligned using labeled standards (data not shown). Densitometric data were corrected as described in Materials and Methods for variations in mRNA loading, as measured by the L32 signal.

against this. (1) Our rats and hamsters were pigmented, and in pigmented rats, constant light does not induce photoreceptor degeneration (LaVail, 1980; Johnson et al., 1999). (2) We compared the histological appearance of paraffin-embedded, cresylstained sections of the retinas of our normal and LR hamsters. Retinas from these two groups were indistinguishable and showed no evidence of photoreceptor degeneration (data not shown). (3) In our pigmented rats, LR and DR differed with respect to the combinations of mRNA and protein changes that they induced in the retina, SC, V1, and CBL (Fig. 1; Table 2).

\section{In the retina, light rearing and dark rearing alter BDNF mRNA and BDNF protein levels}

As in V1, in the rat retina (the hamster retina was not studied), DR reduced BDNF mRNA levels [by $\sim 54 \%$ ( $p=0.001)$; Fig. $1 B$; Table 1]. BDNF mRNA tended to be supernormal in LR rats, although this change did not achieve statistical significance $(p>$ 0.05 ; Fig. $1 B$; Table 1$)$. BDNF protein was decreased by $\sim 27 \%$ in DR rats (Fig. $1 A$; normal, $1.3 \pm 0.1 \mathrm{pg} / \mathrm{mg} ; \mathrm{DR}, 0.9 \pm 0.1 \mathrm{pg} / \mathrm{mg}$; $p=0.009$ ) and, in LR rats, was increased by $\sim 24 \%$ (Fig. $1 A$; $1.6 \pm 0.18 \mathrm{pg} / \mathrm{mg} ; p=0.016)$.

\section{In the hippocampus and cerebellum, light rearing and dark rearing induce changes in BDNF mRNA and protein levels that are not correlated}

To determine whether LR or DR alter the concentrations of BDNF mRNA or protein in nonvisual structures, we measured these parameters in the HIPP and CBL of the rat. Neither LR nor DR caused significant changes in BDNF mRNA levels in the HIPP ( $p>0.05$; Fig. $1 B$; Table 1 ). In the CBL, LR induced a $9 \%$ increase in BDNF mRNA levels $(p=0.012)$, whereas DR had no significant effect. Despite the stability of hippocampal BDNF mRNA levels, BDNF protein was reduced (from its normal value of $24 \pm 1 \mathrm{pg} / \mathrm{mg}$ ) by both rearing conditions (by $36 \%$ after DR, $p=0.0495$; by $47 \%$ after LR, $p=0.0495)$. In the CBL, BDNF protein is increased (from its normal value of $0.9 \pm 0.2 \mathrm{pg} / \mathrm{mg}$ ) by both rearing conditions (by $90 \%$ after DR, $p=0.0495$; by $54 \%$ after LR, $p=0.0495)$, although DR had no significant effect on BDNF mRNA (Fig. 1B; Table 1).

\section{The effects of LR and DR on BDNF mRNA and protein are specific}

The absence of significant LR- or DR-induced changes in collicular BDNF protein levels demonstrates that the changes observed in the retina, V1, CBL, and HIPP are not caused by global abnormalities in BDNF protein metabolism. LR- and DRinduced changes in BDNF mRNA levels exhibit a similar tissue specificity (Fig. $1 B$; Table 1). In each structure studied in these experiments, the pattern of LR- and DR-induced changes varies among the mRNAs for NGF, BDNF, neurotrophin 3 (NT3), and CNTF (G. S. Pollock and D. O. Frost, unpublished observations). Therefore, the LR- and DR-induced changes reported here for BDNF mRNA are not caused by nonspecific effects on mRNA metabolism.

\section{BDNF protein levels undergo diurnal modulation}

In all the structures we examined, there is diurnal modulation of BDNF protein levels. In $\mathrm{V} 1, \mathrm{SC}$, and retina, the tissue concentration of BDNF protein is greater in the middle of the light phase of the circadian cycle than in the middle of the dark phase [Fig. $3 ; 1.45 \times(p=0.0143), 2.18 \times(p=0.003)$, and $1.53 \times(p=$ $0.009)$, respectively]. By contrast, in the CBL and HIPP, BDNF protein levels were less in the middle of the light phase of the diurnal cycle than in the middle of the dark phase [Fig. 3; $0.82 \times$ $(p=0.0433)$ and $0.75 \times(p=0.0204)$, respectively].

These data suggest that our measures of the LR- and DRinduced increases in BDNF protein in V1 and retina are conservative. In our studies of the effects of LR and DR, we killed our animals in the morning, during the light phase of the cycle (i.e., when the BDNF protein concentration in V1 of the normally reared control animals is relatively high). This would bias our data toward a minimum estimate of the magnitude of increases because of experimental rearing. For similar reasons, our measures of the LR- and DR-induced decreases in BDNF protein in HIPP are also conservative.

Table 1. BDNF mRNA

\begin{tabular}{llll} 
& \multicolumn{2}{l}{ Rearing condition } & \\
\cline { 2 - 4 } Structure & Normally reared & Dark-reared & Light-reared \\
\hline V1 & $414.37 \pm 20.52$ & $262.48 \pm 19.51(p=0.003)$ & $442.60 \pm 19.24$ \\
SC & $119.39 \pm 3.98$ & $129.57 \pm 4.01$ & $152.18 \pm 3.97(p=0.002)$ \\
Retina & $145.41 \pm 10.94$ & $67.22 \pm 9.61(p=0.001)$ & $169.47 \pm 10.51$ \\
Hippocampus & $325.56 \pm 11.58$ & $332.83 \pm 15.67$ & $301.43 \pm 13.73$ \\
Cerebellum & $252.07 \pm 5.96$ & $257.20 \pm 5.91$ & $275.64 \pm 5.80(p=0.012)$
\end{tabular}

Tissue concentration of BDNF mRNA [mean \pm SE; units are pixel densities corrected for variation in mRNA loading (see Materials and Methods)]. $p$ values for statistically significant differences from normal are shown in parentheses. 
Table 2. Summary of LR- and DR-induced changes in BDNF mRNA and BDNF protein in the retina, V1, SC, CBL, and HIPP

\begin{tabular}{llll} 
& \multicolumn{2}{l}{ Protein } & \\
\cline { 2 - 3 } mRNA & $=$ & + & - \\
\hline$=^{a}$ & $\mathrm{SC} / \mathrm{DR}, \mathrm{V} 1 / \mathrm{LR}$ & Retina/LR, CBL/DR & HIPP/DR, HIPP/LR \\
+ & $\mathrm{SC} / \mathrm{LR}$ & $\mathrm{CBL} / \mathrm{LR}$ & \\
- & & V1/DR & Retina/DR \\
\hline
\end{tabular}

$\bar{a}=$, No significant change; + , significant increase; - , a significant decrease.

\section{DISCUSSION}

\section{Why does BDNF protein accumulate in V1 of dark-reared animals?}

LR and DR each produce discrepant changes in BDNF mRNA and protein (Fig. 1C; Table 2). Most provocative is the DRinduced increase in cortical BDNF despite a decrease in BDNF mRNA (see also Castrén et al., 1992; Schoups et al., 1995). Discrepancies between BDNF mRNA and protein levels also occur in normal brains and after seizures (Nawa et al., 1995; Elmer et al., 1998). BDNF and trkB are found in the retina, LGN, $\mathrm{SC}$, and V1 during development and at maturity (Allendoerfer et

\section{BDNF PROTEIN}
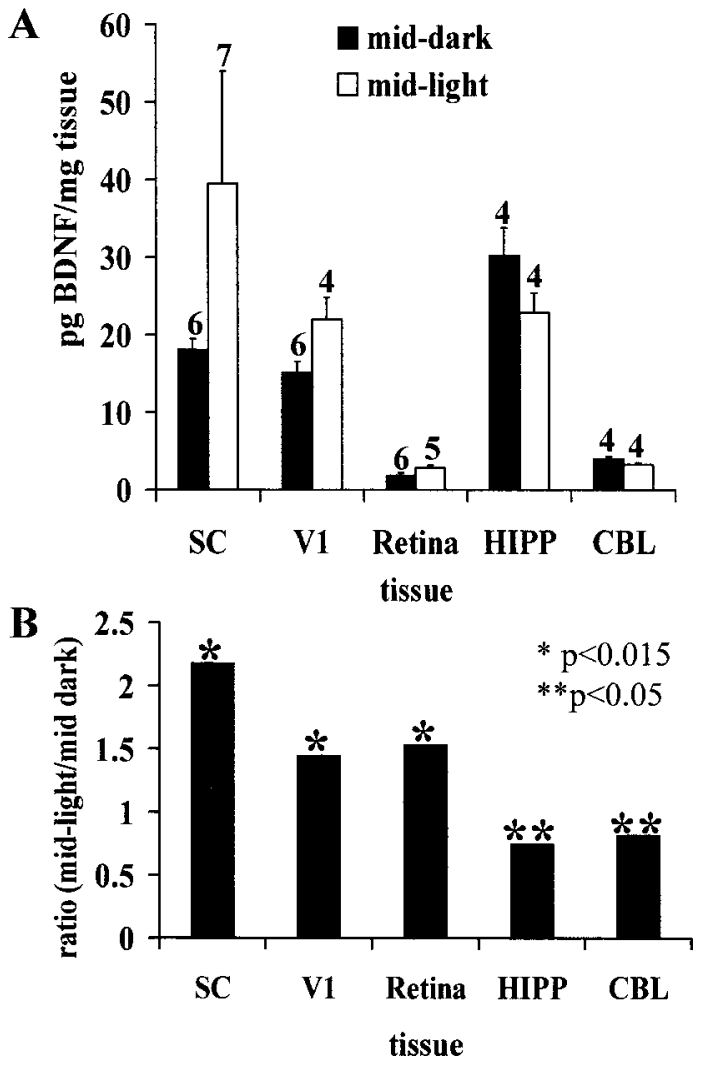

Figure 3. Circadian modulation of BDNF protein levels. $A$, Tissue concentrations of BDNF protein in hamster SC, V1, retina, HIPP, and $\mathrm{CBL}$ in the middle of the light and dark phases of the diurnal cycle. Numerals above each bar indicate the number of independent samples from which data were obtained (see Materials and Methods). $B$, Ratios of the mean BDNF protein concentration in the middle of the light phase of the diurnal cycle to the concentration in the middle of the dark phase. Asterisks indicate the level of statistical significance for differences between light- and dark-phase measurements in $A\left({ }^{*} p<0.015\right.$; ** $\left.p<0.05\right)$.
BDNF ACCUMULATION IN DARK REARED ANIMALS
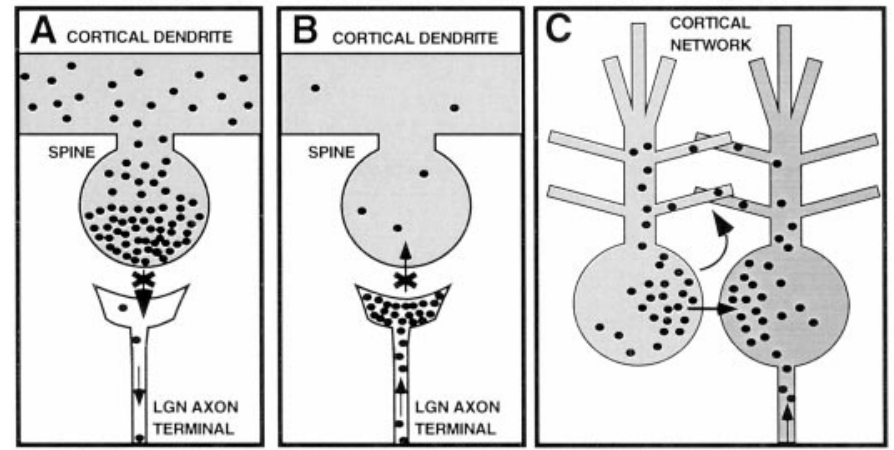

Figure 4. Mechanisms that might account for the accumulation of BDNF protein in $\mathrm{V} 1$ of dark-reared animals. $A$, A reduction in the removal of BDNF by LGN or other afferents (arrow across the synapse). Only axodendritic synapses are depicted, but axosomatic connections are also present. $B$, An accumulation of BDNF delivered to LGN or other afferent presynaptic terminals by anterograde axonal transport. $C$, An increase in the retention of locally synthesized BDNF within cortical networks by transsynaptic, autocrine, or paracrine secretion (arrows between cells). Increased cortical BDNF could also arise by reduced anterograde transport or increased retrograde transport in the axons of cortical efferent neurons (arrow in axon).

al., 1994; Schoups et al., 1995; Ma et al., 1997, 1998) (Frost, Ma, Hsieh, Forbes, and Johnson, unpublished observations). BDNF can be (1) secreted by neurons and removed by afferent axons by retrograde axonal transport (von Bartheld et al., 1996; Ma et al., 1998), (2) packaged within vesicles for anterograde delivery and release from axon terminals (Zhou and Rush, 1996; Altar et al., 1997; Conner et al., 1997; Fawcett et al., 1997; Haubensak et al., 1998; Mowla et al., 1999), and (3) secreted locally to act by autocrine or paracrine pathways (Ghosh et al., 1994). This suggests several mutually compatible hypotheses involving BDNF trafficking as explanations for discrepancies between changes in the levels of BDNF protein and BDNF mRNA.

(1) DR-induced changes in neuronal activity might, by various mechanisms, reduce the removal by afferent axons of BDNF synthesized in V1 (Fig. 4A). Because BDNF secretion is modulated by electrical activity (Griesbeck et al., 1995, 1999; Androutsellis-Theotokis et al., 1996; Goodman et al., 1996; Balkowiec and Katz, 2000), DR might reduce the secretion of BDNF by V1 neurons, causing it to accumulate within them. Because neuronal activity modulates trkB mRNA expression (Gall, 1993; Okazawa et al., 1994) and trafficking (Tongiorgi et al., 1997; Righi et al., 2000) and insertion of trkB protein into membranes (Meyer-Franke et al., 1998; Du et al., 2000), DR could alter the density or type (full-length vs truncated) of trkB receptors on afferent axon terminals, thus reducing the capacity of afferent axons to bind BDNF secreted by V1 neurons. [Qualitative analysis of LGN and V1 of rats reared with monocular eyelid suture reveals no apparent change in the amount or distribution of trkB mRNA (Bozzi et al., 1995). The influence of visual activity on the number, type, or distribution of trkB receptors on cortical afferents is unknown.] Because BDNF increases axonal branching (Cohen-Cory and Fraser, 1995; Inoue and Sanes, 1997) and selectively modifies the growth of cortical neuron dendrites (McAllister et al., 1995, 1999), diminished BDNF secretion or axonal binding might further reduce the density of afferent connections with cortical neurons and, consequently, the access of the afferent axons to cortically derived BDNF. Finally, DR might reduce retrograde $\mathrm{BDNF}$ transport within axons afferent to V1. 
(2) BDNF might accumulate in afferent axon terminals as a consequence of DR-induced changes in neuronal activity (Fig. $4 B$ ). This could occur if BDNF made in LGN or other sources of afferents is anterogradely transported to V1 and if DR either reduces $\mathrm{BDNF}$ release from axon terminals or increases the efficiency of anterograde transport of BDNF. Anterograde BDNF transport accounts for the discrepancy between BDNF protein and mRNA levels in the corpus striatum (Altar et al., 1997).

(3) BDNF might increase in V1 by enhanced retention within local cortical circuits because of DR-induced changes in neuronal activity (Fig. 4C). An increase in the "domestic consumption" of cortical BDNF via transsynaptic, autocrine, or paracrine pathways (Ghosh et al., 1994) could occur by increasing the relative access or binding of BDNF protein by local circuits. Reduced anterograde or increased retrograde axonal transport of BDNF by cortical efferent neurons could also cause its accumulation (Fig. 4C).

The DR-induced accumulation of BDNF in V1 is probably not caused by increased cortical BDNF protein synthesis. Increased production of BDNF protein despite diminished mRNA would require a substantial change in translation efficiency. There are eight variants of BDNF mRNA that can arise via the transcriptional regulation of different promoters. Although increases in specific mRNA transcripts and protein synthesis have been correlated with neural activity (Metsis et al., 1995; Lauterborn et al., 1996), BDNF translation is not increased by a reduction in transcription (Kolbeck et al., 1999), and no increase has been reported as a consequence of neural activity changes.

All of the structures examined in this study contain multiple neuronal populations that differ with respect to their connectivity and their responses to visual stimulation. Our techniques measure only net tissue concentrations of mRNA and protein and provide no information concerning the cellular or subcellular concentrations of either. Therefore, experience-dependent changes in BDNF mRNA or protein levels might vary among different neuronal populations in the same structure.

\section{Other determinants of BDNF mRNA and protein levels}

LR- and DR-induced alterations in BDNF mRNA and protein levels in HIPP and CBL, two structures that receive indirect visual input but that are not primarily sensory, suggest additional regulatory influences. LR and DR could change the level or pattern of motor activity of rat pups. Changes in motor activity alter BDNF mRNA levels in HIPP (Neeper et al., 1996; Oliff et al., 1998); similar changes might also take place in CBL. LR and DR could also alter circulating hormone levels, which influence neurotrophin expression and signaling (Lindholm et al., 1994; Toran-Allerand, 1996; Gibbs, 1998; Toran-Allerand et al., 1999).

\section{Significance of BDNF trafficking for circuit development and synaptic plasticity}

In many mammals, mature, eye-specific afferent axons from LGN segregate in "ocular dominance columns," within which cortical neurons respond preferentially to the corresponding eye (Hubel et al., 1977; Sherman and Spear, 1982). Immature LGN axons representing different eyes initially overlap and then segregate (Hubel et al., 1977; LeVay et al., 1978). This process depends on electrical activity (Katz and Shatz, 1996) and is modulated by visual experience during a postnatal "critical period" when, if one eye is deprived of pattern vision, LGN axon arbors representing the deprived eye narrow excessively and arbors representing the normal eye widen abnormally (Hubel et al., 1977; Sherman and Spear, 1982). The ability of the deprived eye to excite cortical neurons diminishes, and that of the normal eye increases (Hubel et al., 1977; Sherman and Spear, 1982; Fregnac and Imbert, 1984; Gordon and Stryker, 1996). DR reduces the eye-specific segregation of LGN axon arbors in carnivores and prolongs the critical period in rodents and carnivores (Cynader and Mitchell, 1980; Mower et al., 1985; Stryker and Harris, 1986; Swindale, 1988; Fagiolini et al., 1994).

BDNF contributes to these processes. Infusion of V1 with BDNF or NT4 (another high-affinity trkB ligand) blocks the developmental segregation of LGN axons (Cabelli et al., 1995). Cortical infusion with trkB-Fc receptor bodies that deplete endogenous BDNF and NT4 has a similar effect (Cabelli et al., 1997). BDNF and NT4 also modulate the effects of early monocular deprivation on neurophysiologically determined cortical ocular dominance (Galuske et al., 1996; Gillespie et al., 1996) or on the distribution of geniculocortical axons (Hata et al., 2000). The mechanism by which DR-induced increases in cortical BDNF may contribute to the reduced segregation of LGN axons and to changes in the visual response properties of cortical neurons depends on whether or not afferent axon terminals have access to the extra BDNF (Frost, 2001).

Changes in BDNF trafficking could explain other neurophysiological effects of DR. DR decreases the selectivity of V1 neurons for orientation and direction of movement (Fregnac and Imbert, 1984; Benevento et al., 1992; Fagiolini et al., 1994) and increases their spontaneous activity (Benevento et al., 1992). These effects, and comparison of the structural and functional consequences of DR, suggest that DR reduces the efficacy of GABAergic inhibition in V1 (Mower et al., 1985; Swindale and Cynader, 1986; Gabbott and Stewart, 1987; Ramoa et al., 1987; Tsumoto and Freeman, 1987; Swindale, 1988; Fagiolini et al., 1994). DR reduces the number of GABAergic neurons in V1 (Benevento et al., 1995), many of which express trkB (Cellerino et al., 1996). BDNF is necessary for the activity-dependent establishment of GABAmediated inhibition among V1 neurons in vitro (Rutherford et al., 1997) and for the expression of neuropeptide Y, calbindin, and parvalbumin by cortical GABAergic neurons in vivo (Jones et al., 1994). BDNF acts on GABAergic differentiation by activitydependent (Marty et al., 1996a) and activity-independent (Marty et al., 1996b) means. Constitutive overexpression of BDNF accelerates the maturation of visual cortical inhibitory circuitry (Hanover et al., 1999; Huang et al., 1999) and thereby regulates the critical period for vision-induced plasticity (Hanover et al., 1999; Huang et al., 1999; Fagiolini and Hensch, 2000). Thus, a DR-induced reduction in the availability of BDNF to GABAergic neurons could explain the reduced GABAergic tone and prolonged critical period in V1 of DR animals. Reduced BDNF availability could also shift upward the threshold at which the effect of presynaptic activity changes from synaptic depression to potentiation (Bienenstock et al., 1982; Bear et al., 1987). This would reduce the stimulus selectivity of cortical neurons by diminishing the specificity of activity-dependent elimination of immature connections.

\section{Circadian changes}

In mature hamsters, BDNF protein levels in the retina, $\mathrm{V} 1$, and SC are $\sim 1.5-2.2$ times greater in the middle of the light phase of the diurnal cycle than in the middle of the dark phase. Similarly, retinal BDNF mRNA is rapidly downregulated in the chick retina when chicks are moved from light to dark (Karlsson and 
Hallböök, 1998). These data are consistent with the regulation of BDNF mRNA expression by neuronal activity (see introductory remarks), which in these structures is elevated by visual stimulation. Why do cortical BDNF protein levels decrease during the dark phase of the diurnal cycle but increase after DR? Chronic, DR-induced reductions in BDNF secretion or changes in BDNF trafficking could cause BDNF protein to accumulate in V1 (see above). The regular modulation of BDNF protein secretion and trafficking during a normal light/dark cycle would prevent such an accumulation, thus revealing the relatively small decrease in BDNF protein during the dark phase.

We found that in HIPP and CBL, BDNF protein is elevated during the dark phase of the diurnal cycle, consistent with the increase in BDNF mRNA in HIPP during the dark phase (Bova et al., 1998; Berchtold et al., 1999; Schaaf et al., 2000). Hippocampal BDNF mRNA levels are increased by motor activity (Neeper et al., 1996; Oliff et al., 1998). Because rodents are active during the dark phase of the diurnal cycle and sleep during the light phase, the circadian modulation of BDNF protein in the CBL and HIPP is probably caused, in part, by elevated nocturnal motor and cognitive activity. Diurnal changes in hormone levels could also contribute to the circadian modulation of BDNF mRNA and protein (Lindholm et al., 1994; Toran-Allerand, 1996; Gibbs, 1998; Toran-Allerand et al., 1999). Because of the profound effects of BDNF on synaptic efficacy (Thoenen, 1995; Schuman, 1999), our data suggest that circadian changes in BDNF levels could contribute to diurnal fluctuations in synaptic function in some neural circuits.

\section{REFERENCES}

Allendoerfer KL, Cabelli RJ, Escandon E, Kaplan DR, Nikolics K, Shatz CJ (1994) Regulation of neurotrophin receptors during the maturation of the mammalian visual system. J Neurosci 14:1795-1811.

Altar CA, Cai N, Bliven T, Juhasz M, Conner JM, Acheson AL, Lindsay RM, Wiegand SJ (1997) Anterograde transport of brain-derived neurotrophic factor and its role in the brain. Nature 389:856-860.

Androutsellis-Theotokis A, McCormack WJ, Bradford HF, Stern GM, Pliego-Rivero F (1996) The depolarisation-induced release of [125I]BDNF from brain tissue. Brain Res 743:40-48.

Balkowiec A, Katz DM (2000) Activity-dependent release of endogenous brain-derived neurotrophic factor from primary sensory neurons detected by ELISA in situ. J Neurosci 20:7417-7423.

Bear MF, Cooper LN, Ebner FF (1987) A physiological basis for a theory of synapse modification. Science 237:42-48.

Benevento LA, Bakkum BW, Port JD, Cohen RS (1992) The effects of dark-rearing on the electrophysiology of the rat visual cortex. Brain Res 572:198-207.

Benevento LA, Bakkum BW, Cohen RS (1995) Gamma-aminobutyric acid and somatostatin immunoreactivity in the visual cortex in normal and dark-reared rats. Brain Res 689:172-182.

Berchtold NC, Oliff HS, Isackson P, Cotman CW (1999) Hippocampal BDNF mRNA shows a diurnal regulation, primarily in the exon III transcript. Mol Brain Res 71:11-22.

Bessho Y, Nakanishi S, Nawa H (1993) Glutamate receptor agonists enhance the expression of BDNF mRNA in cultured cerebellar granule cells. Mol Brain Res 18:201-208.

Bienenstock EL, Cooper LN, Munrow PW (1982) Theory for the development of neuron selectivity: orientation specificity and binocular interaction in the visual cortex. J Neurosci 2:32-48.

Bova R, Micheli MR, Qualadrucci P, Zucconi GG (1998) BDNF and trkB mRNAs oscillate in rat brain during the light-dark cycle. Mol Brain Res 57:321-324.

Bozzi Y, Pizzorusso T, Cremist F, Rossi FM, Barsacchi G, Maffei L (1995) Monocular deprivation decreases the expression of messenger RNA for brain-derived neurotrophic factor in the rat visual cortex. Neuroscience 69:1133-1144.

Cabelli RJ, Hohn A, Shatz CJ (1995) Inhibition of ocular dominance column formation by infusion of NT-4/5 or BDNF. Science 267:1662-1666.

Cabelli RJ, Shelton DL, Segal RA, Shatz CJ (1997) Blockade of endogenous ligands of trkB inhibits formation of ocular dominance columns. Neuron 19:63-76.

Castrén E, Zafra F, Thoenen H, Lindholm D (1992) Light regulates expression of brain-derived neurotrophic factor mRNA in rat visual cortex. Proc Natl Acad Sci USA 89:9444-9448.

Causing CG, Gloster A, Aloyz RS, Bamji SX, Chang E, Fawcett JP, Kuchel G, Miller FD (1997) Synaptic innervation density is regulated by neuron-derived BDNF. Neuron 18:257-267.

Cellerino A, Maffei L, Domenici L (1996) The distribution of brainderived neurotrophic factor and its receptor trkB in parvalbumincontaining neurons of the rat visual cortex. Eur $\mathrm{J}$ Neurosci 8:1190-1197.

Cohen-Cory S (1999) BDNF modulates, but does not mediate, activitydependent branching and remodeling of optic axon arbors in vivo. J Neurosci 19:9996-10003.

Cohen-Cory S, Fraser SE (1995) Effects of brain-derived neurotrophic factor on optic axon branching and remodelling in vivo. Nature 378:192-196.

Conner JM, Lauterborn JC, Yan Q, Gall CM, Varon S (1997) Distribution of brain-derived neurotrophic factor (BDNF) protein and mRNA in the normal rat CNS: evidence for anterograde axonal transport. J Neurosci 17:2295-2313.

Cowan WM, Fawcett JW, O'Leary DDM, Stanfield BB (1984) Regressive events in neurogenesis. Science 225:1258-1265.

Cynader MS, Mitchell DE (1980) Prolonged sensitivity to monocular deprivation in dark-reared cats. J Neurophysiol 43:1026-1040.

Domenici L, Berardi N, Carmignoto G, Vantini G, Maffei L (1991) Nerve growth factor prevents the amblyopic effects of monocular deprivation. Proc Natl Acad Sci USA 88:8811-8815.

Du J, Feng L, Feng Y, Lu B (2000) Activity- and $\mathrm{Ca}^{2+}$-dependent modulation of surface expression of brain-derived neurotrophic factor receptors in hippocampal neurons. J Cell Biol 150:1423-1433.

Elmer E, Kokaia Z, Kokaia M, Carnahan J, Nawas H, Lindvall O (1998) Dynamic changes of brain derived neurotrophic factor protein levels in the rat forebrain after single and recurring kindling-induced seizures. Neuroscience 83:351-362.

Fagiolini M, Hensch TK (2000) Inhibitory threshold for critical-period activation in primary visual cortex. Nature 404:183-186.

Fagiolini M, Pizzorusso Y, Berardi N, Domenici L, Maffei L (1994) Functional postnatal development of the rat primary visual cortex and the role of visual experience: dark rearing and monocular deprivation. Vision Res 34:709-720.

Fawcett JP, Aloyz RS, McLean JH, Pareek S, Miller FD, McPherson PS, Murphy RA (1997) Detection of brain-derived neurotrophic factor in a vesicular fraction of brain synaptosomes. J Biol Chem 272:8837-8840.

Fawcett JP, Bamii SX, Causing CG, Aloyz RS, Ase AR, Reader TA, McLean JH, Miller FD (1998) Functional evidence that BDNF is an anterograde neuronal trophic factor in the CNS. J Neurosci 18:2808-2821.

Fregnac Y, Imbert M (1984) Development of neuronal selectivity in primary visual cortex of cat. Physiol Rev 64:325-434.

Frost DO (2001) BDNF/trkB signaling in the developmental sculpting of visual connections. Prog Brain Res, in press.

Frost DO, Innocenti GM (1986) Effects of sensory experience on the development of visual callosal connections. In: Two hemispheres-one brain (Lepore F, Ptito M, Jasper H, eds), pp 255-266. New York: Liss.

Gabbott PL, Stewart MG (1987) Quantitative morphological effects of dark-rearing and light exposure on the synaptic connectivity of layer 4 in the rat visual cortex (area 17). Exp Brain Res 68:103-114.

Gall CM (1993) Seizure-induced changes in neurotrophin expression: implications for epilepsy. Exp Neurol 124:150-166.

Gall CM, Guthrie K, Lauterborn JC (1995) Stimulation of neurotrophic factor expression: links to different forms of brain plasticity. In: Life and death in the nervous system (Ibanez CF, ed), pp 275-295. Oxford: Elsevier.

Galuske R, Kim D, Castrén E, Thoenen H, Singer W (1996) Brainderived neurotrophic factor reverses experience-dependent synaptic modifications in kitten visual cortex. Eur J Neurosci 8:1554-1559.

Ghosh A, Carnahan J, Greenberg ME (1994) Requirement for BDNF in activity-dependent survival of cortical neurons. Science 263:1618-1623.

Gibbs RB (1998) Levels of trkA and BDNF mRNA, but not NGF mRNA, fluctuate across the estrous cycle and increase in response to acute hormone replacement. Brain Res 787:259-268.

Gillespie DC, Crair MC, Stryker MP (1996) NT4/5 infusion alters plasticity and responses of cat primary visual cortex during the critical period. Soc Neurosci Abstr 22:276.

Goodman L, Valverde J, Lim F, Geschwind M, Federoff H, Geller A, Hefti F (1996) Regulated release and polarized localization of brainderived neurotrophic factor in hippocampal neurons. Mol Cell Neurosci 7:222-238.

Gordon JA, Stryker MP (1996) Experience-dependent plasticity of binocular responses in the primary visual cortex of the mouse. J Neurosci $16: 3274-3286$

Griesbeck O, Blöchl A, Carnahan JF, Nawa H, Thoenen H (1995) Characterization of brain-derived neurotrophic factor (BDNF) secretion from hippocampal neurons. Soc Neurosci Abstr 21:1046.

Griesbeck O, Canossa M, Campana G, Gartner A, Hoener MC, Nawa H, 
Kolbeck R, Thoenen H (1999) Are there differences between the secretion characteristics of NGF and BDNF? Implications for the modulatory role of neurotrophins in activity-dependent neuronal plasticity. Microsc Res Tech 45:262-275.

Hanover JL, Huang ZJ, Tonegawa S, Stryker MP (1999) Brain-derived neurotrophic factor overexpression induces precocious critical period in mouse visual cortex. J Neurosci 19:RC40.

Hata Y, Ohshima M, Ichisaka S, Wakita M, Fukuda M, Tsumoto T (2000) Brain-derived neurotrophic factor expands ocular dominance columns in visual cortex in monocularly deprived and non-deprived kittens but does not in adult cats. J Neurosci 20:RC57.

Haubensak W, Narz F, Heumann R, LeBmann V (1998) BDNF-GFP containing secretory granules are localized in the vicinity of synaptic junctions of cultured cortical neurons. J Cell Sci 111:1483-1493.

Horch HW, Krüttgen A, Portbury SD, Katz LC (1999) Destabilization of cortical dendrites and spines by BDNF. Neuron 23:353-364.

Huang ZJ, Kirkwood A, Pizzorusso T, Porciatti V, Morales B, Bear MF, Maffei L, Tonegawa S (1999) BDNF regulates the maturation of inhibition and the critical period of plasticity in mouse visual cortex. Cell 98:739-755.

Hubel DH, Wiesel TN, LeVay S (1977) Plasticity of ocular dominance columns in monkey striate cortex. Philos Trans R Soc Lond [Biol] 278:377-409

Inoue A, Sanes JR (1997) Lamina-specific connectivity in the brain: regulation by $\mathrm{N}$-cadherin, neurotrophins and glycoconjugates. Science 276:1428-1431.

Johnson EC, LaVail MM, Cepurna WO, Jia L, Ackhavong K, Morrison JC (1999) Housing in low level, constant light stabilizes circadian intraocular pressure (IOP) oscillations in brown norway rats, simplifying a glaucomatous neuropathy model. Invest Ophthalmol Vis Sci 40:S672.

Jones KR, Fariñas I, Backus C, Reichardt LF (1994) Targeted disruption of the BDNF gene perturbs brain and sensory neuron development but not motor neuron development. Cell 76:989-999.

Karlsson M, Hallböök F (1998) Kainic acid, tetrodotoxin and light modulate expression of brain-derived neurotrophic factor in developing avian retinal ganglion cells and their tectal target. Neuroscience 83:137-150.

Katz LC, Shatz CJ (1996) Synaptic activity and the construction of cortical circuits. Science 274:1133-1138.

Knipper M, Berzaghi MP, Blöchl A, Breer H, Thoenen H, Lindholm D (1994) Positive feedback between acetylcholine and the neurotrophins nerve growth factor and brain-derived neurotrophic factor. Eur J Neurosci 6:668-671.

Kolbeck R, Bartke I, Eberle W, Barde Y-A (1999) Brain-derived neurotrophic factor levels in the nervous system of wild-type and neurotrophin gene mutant mice. J Neurochem 72:1930-1938.

Lauterborn JC, Rivera S, Stinis CT, Hayes VY, Isackson PJ, Gall CM (1996) Differential effects of protein synthesis inhibition on the activity-dependent expression of BDNF transcripts: evidence for immediate-early gene responses from specific promoters. J Neurosci 16:7428-7436.

LaVail MM (1980) Eye pigmentation and constant light damage in the rat retina. In: The effects of constant light on visual processes (Williams TP, Baker B, eds), pp 357-387. New York: Plenum.

Lein E, Hohn A, Shatz CJ (1997) Rapid regulation of BDNF mRNA by afferent activity in the visual system. Soc Neurosci Abstr 23:47.

Lein ES, Hohn A, Shatz CJ (2000) Dynamic regulation of BDNF and NT-3 expression during visual system development. J Comp Neurol 420:1-18.

LeVay S, Stryker MP, Shatz CJ (1978) Ocular dominance columns and their development in layer IV of the cat's visual cortex: a quantitative study. J Comp Neurol 179:223-244.

Lewin GR, Barde Y-A (1996) Physiology of the neurotrophins. Annu Rev Neurosci 19:289-317.

Lindefors N, Ernfors P, Falkenberg T, Persson H (1992) Septal cholinergic afferents regulate expression of brain-derived neurotrophic factor and beta-nerve growth factor mRNA in rat hippocampus. Exp Brain Res 88:78-90.

Lindholm D, Castren E, Berzaghi MP, Blöchl A, Thoenen H (1994) Activity-dependent and hormonal regulation of neurotrophin mRNA levels in brain: implications for neuronal plasticity. J Neurobiol 25:1362-1372.

Lom B, Cohen-Cory S (1999) Brain-derived neurotrophic factor differentially regulates retinal ganglion cell dendritic and axonal arborization in vivo. J Neurosci 19:9928-9938.

Ma Y-T, Hsieh T, Forbes ME, Johnson JE, Frost DO (1997) BDNF protein levels in developing hamster visual system. Soc Neurosci Abstr 23:329.

Ma Y-T, Hsieh T, Forbes ME, Johnson JE, Frost DO (1998) BDNF injected into the superior colliculus reduces developmental retinal ganglion cell death. J Neurosci 18:2097-2107.

Marty S, Berninger B, Carroll P, Thoenen H (1996a) GABAergic stimulation regulates the phenotype of hippocampal interneurons through the regulation of brain-derived neurotrophic factor. Neuron 16:565-570

Marty S, Carroll P, Cellerino A, Castren E, Staiger V, Thoenen H, Lindholm D (1996b) Brain-derived neurotrophic factor promotes the differentiation of various hippocampal nonpyramidal neurons, including Cajal-Retzius cells, in organotypic slice cultures. J Neurosci 16:675-687.

McAllister AK, Lo DC, Katz LC (1995) Neurotrophins regulate dendritic growth in developing visual cortex. Neuron 15:791-803.

McAllister AK, Katz LC, Lo DC (1999) Neurotrophins and synaptic plasticity. Annu Rev Neurosci 22:295-318.

Metsis M, Timmusk T, Salin T (1995) Structure and regulation of BDNF and NT-4 genes. In: Life and death in the nervous system (Ibanez CF, ed), pp 235-259. Oxford: Elsevier.

Meyer-Franke A, Wilkinson GA, Kruttgen A, Hu M, Munro E, Hanson MG, Reichardt LF, Barres BA (1998) Depolarization and cAMP elevation rapidly recruit trkB to the plasma membrane of CNS neurons. Neuron 21:681-693

Miller KD, Keller JB, Stryker MP (1989) Ocular dominance column development: analysis and simulation. Science 245:605-615.

Mower GD, Caplan CJ, Christen WG, Duffy FH (1985) Dark rearing prolongs physiological but not anatomical plasticity of the cat visual cortex. J Comp Neurol 235:448-466.

Mowla SJ, Pareek S, Farhadi HF, Petrecca K, Fawcett JP, Seidah NG, Morris SJ, Sossin WS, Murphy RA (1999) Differential sorting of nerve growth factor and brain-derived neurotrophic factor in hippocampal neurons. J Neurosci 19:1-12.

Nawa H, Carnahan J, Gall CM (1995) BDNF protein measured by a novel enzyme immunoassay in normal brain and after seizure: partial disagreement with mRNA levels. Eur J Neurosci 7:1527-1535.

Neeper SA, Gomez-Pinilla F, Choi J, Cotman CW (1996) Physical activity increases mRNA for brain-derived neurotrophic factor and nerve growth factor. Brain Res 726:49-56.

Okazawa H, Kamei M, Imafuku I, Kanazawa I (1994) Gene regulation of trkB and trkC in the chick retina by light/darkness exposure. Oncogene 9:1813-1818.

Oliff HS, Berchtold NC, Isackson P, Cotman CW (1998) Exerciseinduced regulation of brain-derived neurotrophic factor (BDNF) transcripts in the rat hippocampus. Mol Brain Res 61:147-153.

O'Steen WK, Anderson KV, Shear CR (1974) Photoreceptor degeneration in albino rats: dependency on age. Invest Ophthalmol 13:334-339.

Patterson SL, Grover LM, Schwartzkroin PA, Bothwell M (1992) Neurotrophin expression in rat hippocampal slices: a stimulus paradigm inducing LTP in CA1 evokes increases in BDNF and NT-3 mRNAs. Neuron 9:1081-1088.

Ramoa AS, Shadlen M, Freeman RD (1987) Dark-reared cats: unresponsive cells become visually responsive with microiontophoresis of an excitatory amino acid. Exp Brain Res 65:658-665.

Righi M, Tongiorgi E, Cattaneo A (2000) Brain-derived neurotrophic factor $(\mathrm{BDNF})$ induces dendritic targeting of $\mathrm{BDNF}$ and tyrosine kinase B mRNAs in hippocampal neurons through a phosphatidylinositol-3 kinase-dependent pathway. J Neurosci 20:3165-3174.

Rutherford LC, DeWan A, Lauer HM, Turrigiano GG (1997) Brainderived neurotrophic factor mediates the activity-dependent regulation of inhibition in neocortical cultures. J Neurosci 17:4527-4535.

Schaaf MJ, Duurland R, deKloet ER, Vreugdenhil E (2000) Circadian variation in BDNF mRNA expression in the rat hippocampus. Mol Brain Res 75:342-344.

Schoups AA, Elliott RC, Friedman WJ, Black IB (1995) NGF and BDNF are differentially modulated by visual experience in the developing geniculocortical pathway. Brain Res 86:326-334.

Schuman EM (1999) Neurotrophin regulation of synaptic transmission. Curr Opin Neurobiol 9:105-109.

Schwartz PM, Borghesani PR, Levy RL, Pomeroy SL, Segal RA (1997) Abnormal cerebellar development and foliation in $\mathrm{BDNF}-/-$ mice reveals a role for neurotrophins in CNS patterning. Neuron 19:269-281.

Shatz CJ (1997) Neurotrophins and visual system plasticity. In: Molecular and cellular approaches to neural development (Cowan M, Jessell T, Zipursky S, eds), pp 509-524. New York: Oxford UP.

Sherman SM, Spear PD (1982) Organization of visual pathways in normal and visually deprived cats. Physiol Rev 62:738-855.

Smith MA, Zhang L-X, Lyons WE, Mamounas LA (1997) Anterograde transport of endogenous brain-derived neurotrophic factor in hippocampal mossy fibers. NeuroReport 8:1829-1834.

Snider WD, Lichtman JW (1996) Are neurotrophins synaptotrophins? Mol Cell Neurosci 7:433-442.

Stryker MP, Harris WA (1986) Binocular impulse blockade prevents the formation of ocular dominance columns in cat visual cortex. J Neurosci 6:2117-2133.

Swindale NV (1988) Role of visual experience in promoting segregation of eye dominance patches in the visual cortex of the cat. J Comp Neurol 267:472-488.

Swindale NV, Cynader MS (1986) Physiological segregation of geniculo- 
cortical afferents in the visual cortex of dark-reared cats. Brain Res 362:281-286.

Thoenen H (1995) Neurotrophins and neuronal plasticity. Science 270:593-598.

Tongiorgi E, Righi M, Cattaneo A (1997) Activity-dependent dendritic targeting of BDNF and trkB mRNA in hippocampal neurons. J Neurosci 17:9492-9505.

Toran-Allerand CD (1996) The estrogen/neurotrophin connection during neural development: is co-localization of estrogen receptors with the neurotrophins and their receptors biologically relevant? Dev Neurosci 18:36-48.

Toran-Allerand CD, Singh M, Setalo Jr G (1999) Novel mechanisms of estrogen action in the brain: new players in an old story. Front Neuroendocrinol 20:97-121.

Tsumoto T, Freeman RD (1987) Dark-reared cats: responsivity of cortical cells influenced pharmacologically by an inhibitory antagonist. Exp Brain Res 65:666-672.

von Bartheld CS, Williams R, Lefcort F, Clary DO, Reichardt LF, Bothwell M (1996) Retrograde transport of neurotrophins from the eye to the brain in chick embryos: roles of the p75NTR and trkB receptors. J Neurosci 16:2995-3008.

Xu B, Zang K, Ruff N, Zhang YA, McConnell S, Stryker M, Reichardt L (2000) Cortical degeneration in the absence of neurotrophin signaling: dendritic retraction and neuronal loss after removal of the receptor trkB. Neuron 26:233-245.

Yan Q, Rosenfeld RD, Matheson CR, Hawkins N, Lopez OT, Bennett L, Welcher AA (1997) Expression of brain-derived neurotrophic factor protein in the adult rat central nervous system. Neuroscience 78:431-448.

Zafra F, Hengerer B, Liebrock J, Thoenen H, Lindholm D (1990) Activity dependent regulation of BDNF and NGF mRNAs in the rat hippocampus is mediated by non-NMDA glutamate receptors. EMBO J 9:3545-3550.

Zafra F, Castrén E, Thoenen H, Lindholm D (1991) Interplay between glutamate and gamma-amino butyric acid transmitter systems in the physiological regulation of brain-derived neurotrophic factor and nerve growth factor synthesis in hippocampal neurons. Proc Natl Acad Sci USA 88:10037-10041.

Zafra F, Castren E, Lindholm D, Hartikka J, Thoenen H (1992) Regulation of brain-derived neurotrophic factor and nerve growth factor mRNA in primary cultures of hippocampal neurons and astrocytes. J Neurosci 12:4793-4799.

Zhou X-F, Rush RA (1996) Endogenous brain-derived neurotrophic factor is anterogradely transported in primary sensory neurons. Neuroscience 74:945-951. 